\title{
THE PRESERVATION OF TWO MILITARY FUTURO-HOUSES
}

\author{
INGELA ANDERSSON \& KARL-MARTIN SVÄRD \\ Swedish Fortifications Agency, Sweden.
}

\begin{abstract}
In the beginning of the 1970s, the Swedish Armed Forces bought three specially adapted Futuro-houses to use on top of observation towers at training areas. Two of the three Futuro-houses were used as observation towers at the Noran training area in the middle of Sweden. In 1998, the area was closed down and now one of the Futuro-houses is sold and the other one transferred to the Swedish Air Force Museum. The third is still in use at another military airfield. The removal of the Futuro-houses was the second best way to make at least one of them publicly accessible at a museum.

Keywords: air force, Futuro-houses, observation towers, reuse
\end{abstract}

\section{INTRODUCTION}

In 2014, a journalist raised a question about preserving two observation towers as cultural heritage. The towers had been used for measuring impact points at a former military training area for air bombing at Noran training area outside of Söderhamn. No one within the Swedish Fortifications Agency or the Swedish Armed Forces had thought much about the two towers no longer in use. The towers in question are two out of three Futuro-houses bought by the Swedish Armed Forces in the beginning of the 1970s specially adapted to military use.

\section{THE NORAN TARGET AREA}

The Futuro-houses on Noran military training area were abandoned by the Swedish armed forces following the 2004 political decision to further decrease the number of active training areas. This was done in retrospect of the end of the Cold War and the decreased need for airbases in Sweden. Noran had served as the principal target area for the pilots of the 15th airbase located in nearby Söderhamn. The airbase was active on Noran from 1945 to 1998 (Figs. 1 and 2).

\section{THE FUTURO-HOUSE}

The two towers have an interesting military as well as a design history. Finnish architect Matti Suuronen originally designed the Futuro-house in 1968 as a ski lodge. It was constructed of a plastic material in eight sections and was easy to assemble and place wherever you wanted to have your winter or summer house. At Noran, they were lifted in place by a military helicopter.

The designer himself claimed that the design was based on pi, 3.14. There are similarities both with contemporary design and with architecture, for example Eero Aarnios Ball Chair in fibre glass from 1963 or the moveable 'capsule houses' designed by the Archgram group. Others associate the Futuro-houses with Unidentified Flying Objects (UFOs) and see it as a part of a space age design [1].

The house has a diameter of $8 \mathrm{~m}$, and the original design came completely equipped with custom furnishings that fit the interesting shape of the house. The designs of the military 


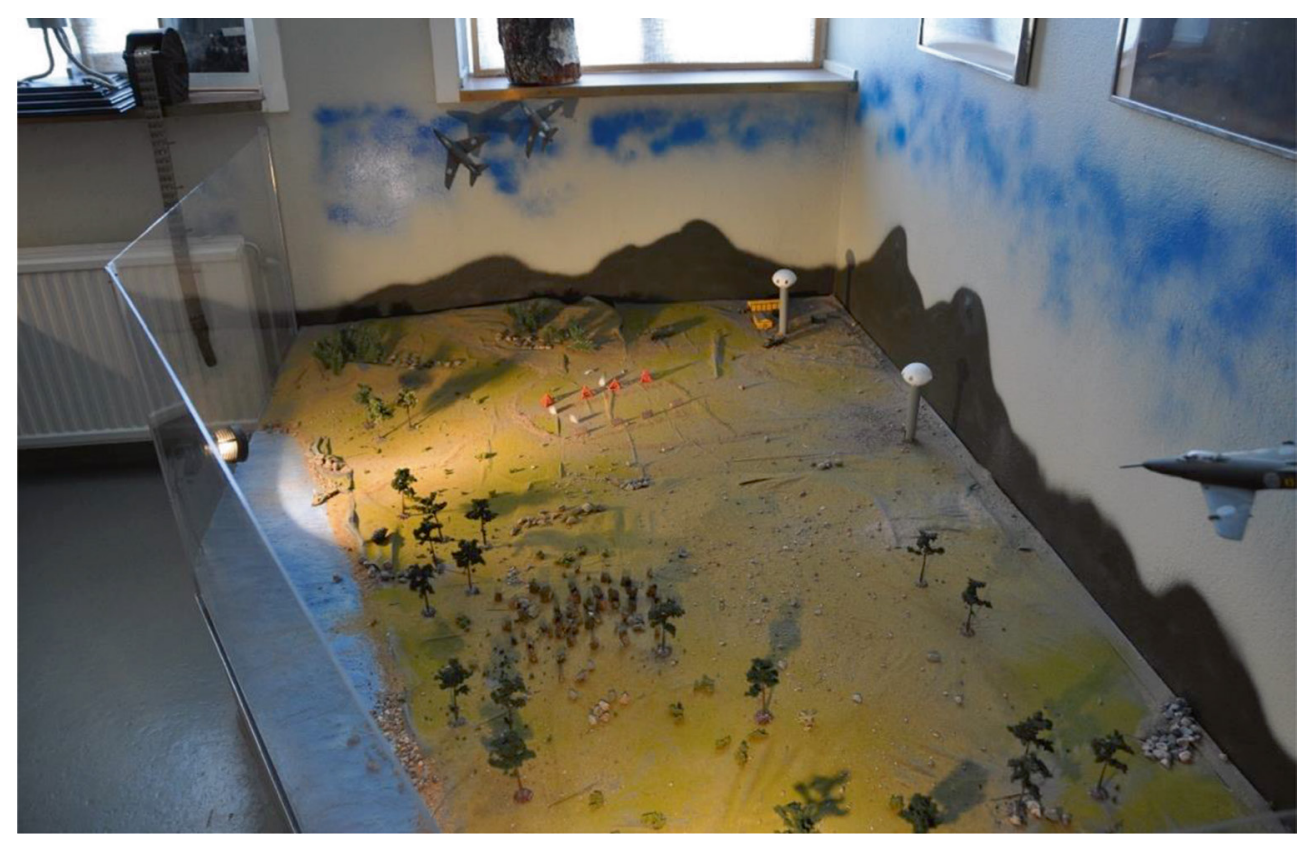

Figure 1: A model of the Noran target area at Söderhamn/F15 Air Force Museum. (@ Photo from the Swedish Fortifications Agency with Ingela Andersson as photographer.)

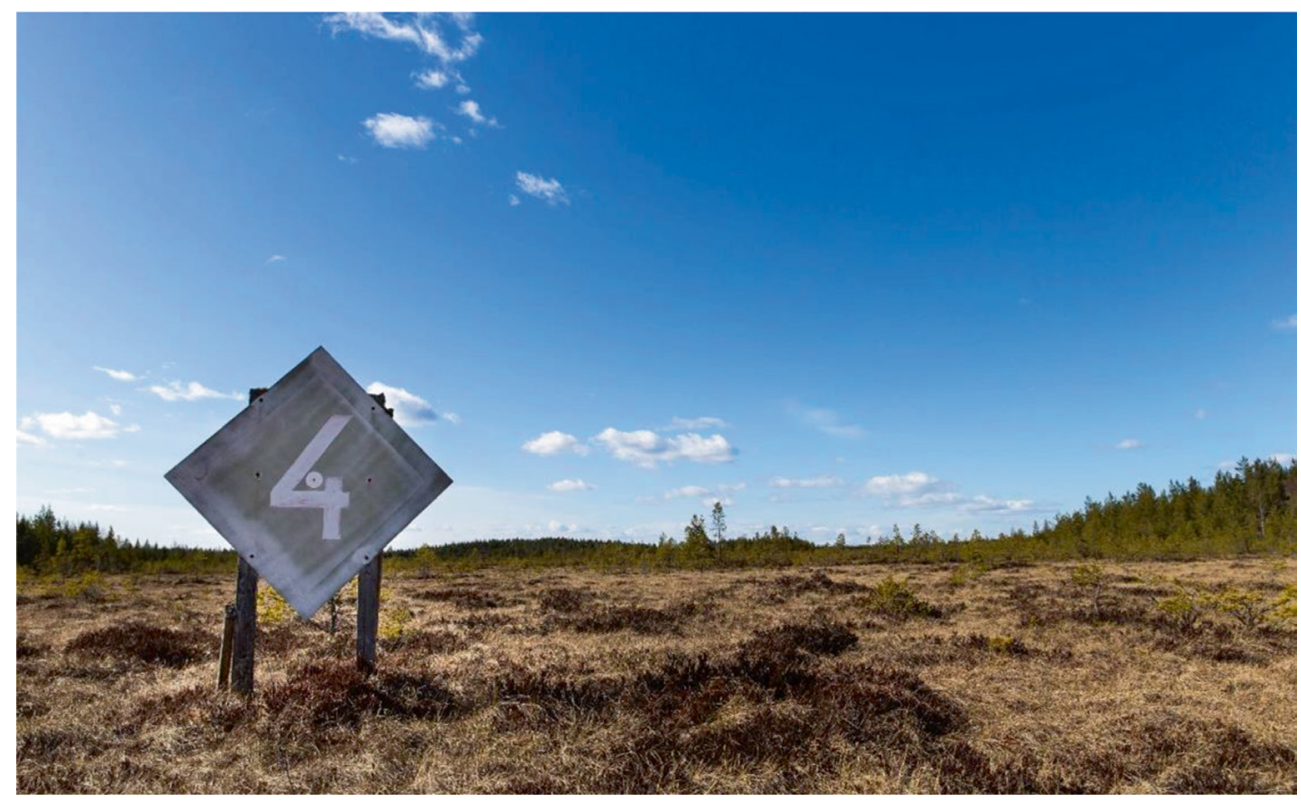

Figure 2: The Noran target area today. (C) Photo from the Swedish Fortifications Agency with Johan Danielson as photographer.) 
versions were altered to fit on top of the concrete towers and to their use as military observation towers (Figs. 3 and 4).

Instead of entering the house through an airplane like flight of stairs, you had to enter the military ones climbing a ladder through a tube in the middle of the tower, originally the place

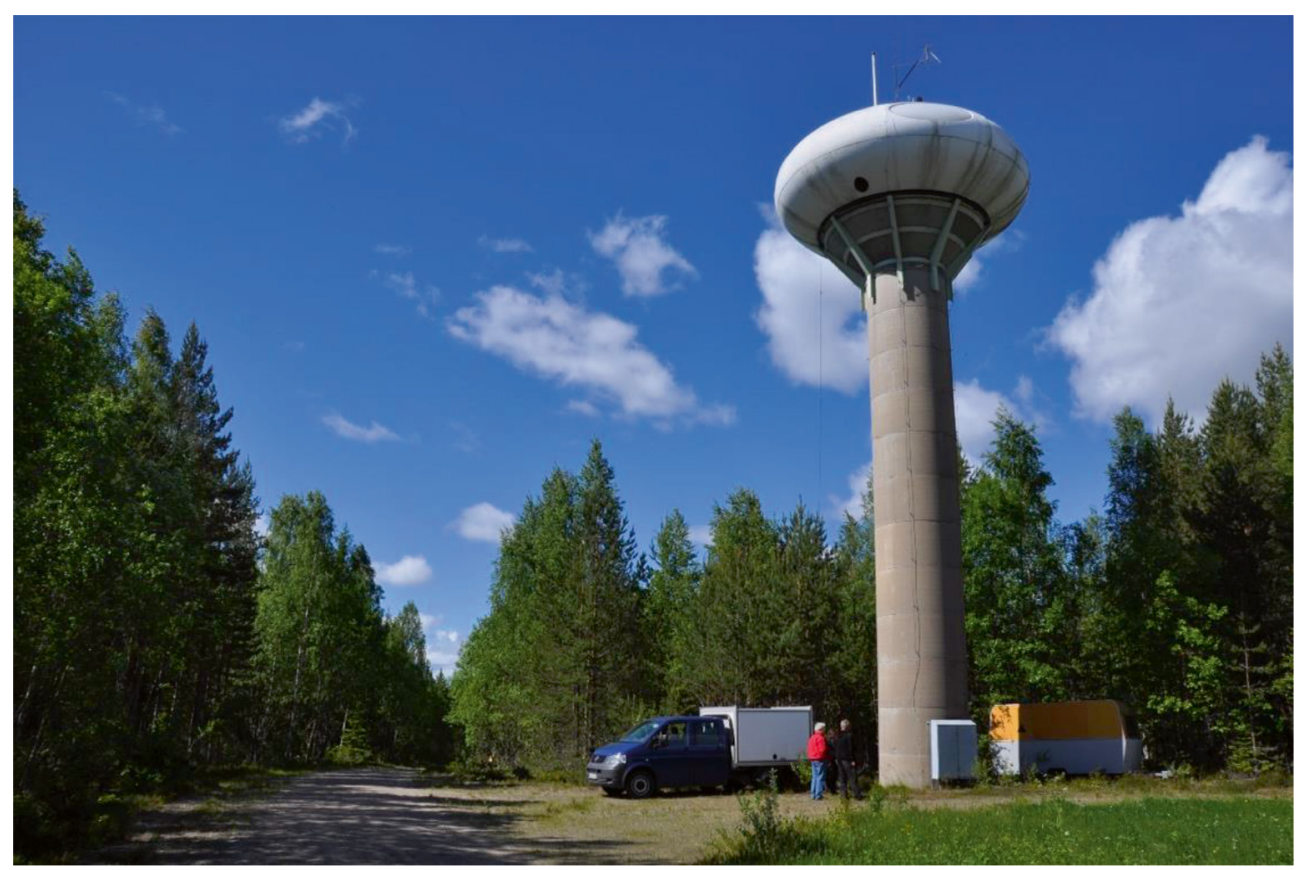

Figure 3: Tower no. 1. (@ Photo from the Swedish Fortifications Agency with Ingela Andersson as photographer.)

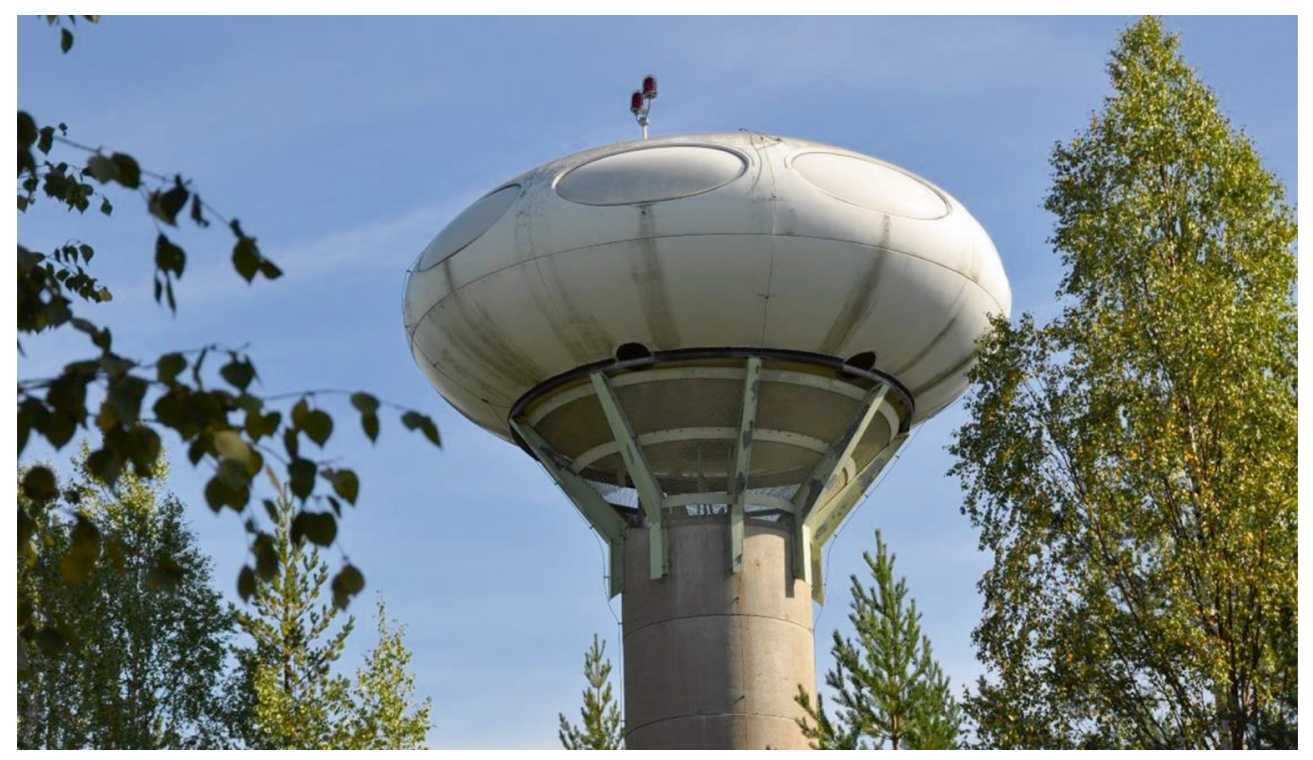

Figure 4: Tower no. 2. (@ Photo from the Swedish Fortifications Agency with Ingela Andersson as photographer.) 
for a fireplace. Instead of furniture, the houses were fitted with platforms with desks to facilitate working in the towers (Figs. 5-7).

The Futuro-house is a circular construction divided into eight sections, originally with two oval windows in each section. The military version has only one large window in each section to make it easier to see the impact points. Working conditions in the towers though were not very good. In the summer, it could be very hot and in the winter freezing cold.

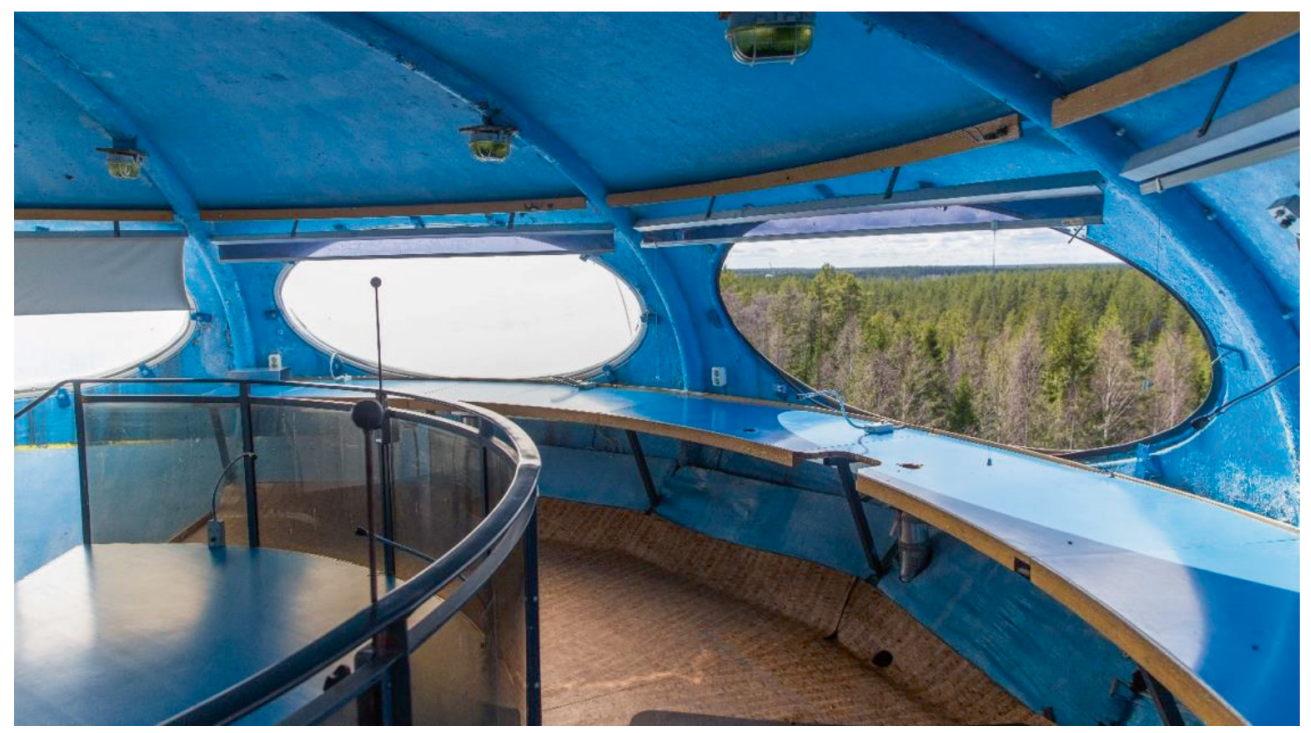

Figure 5: Interior, tower no. 2. (@) Photo from the Swedish Fortifications Agency with Johan Danielson as photographer.)

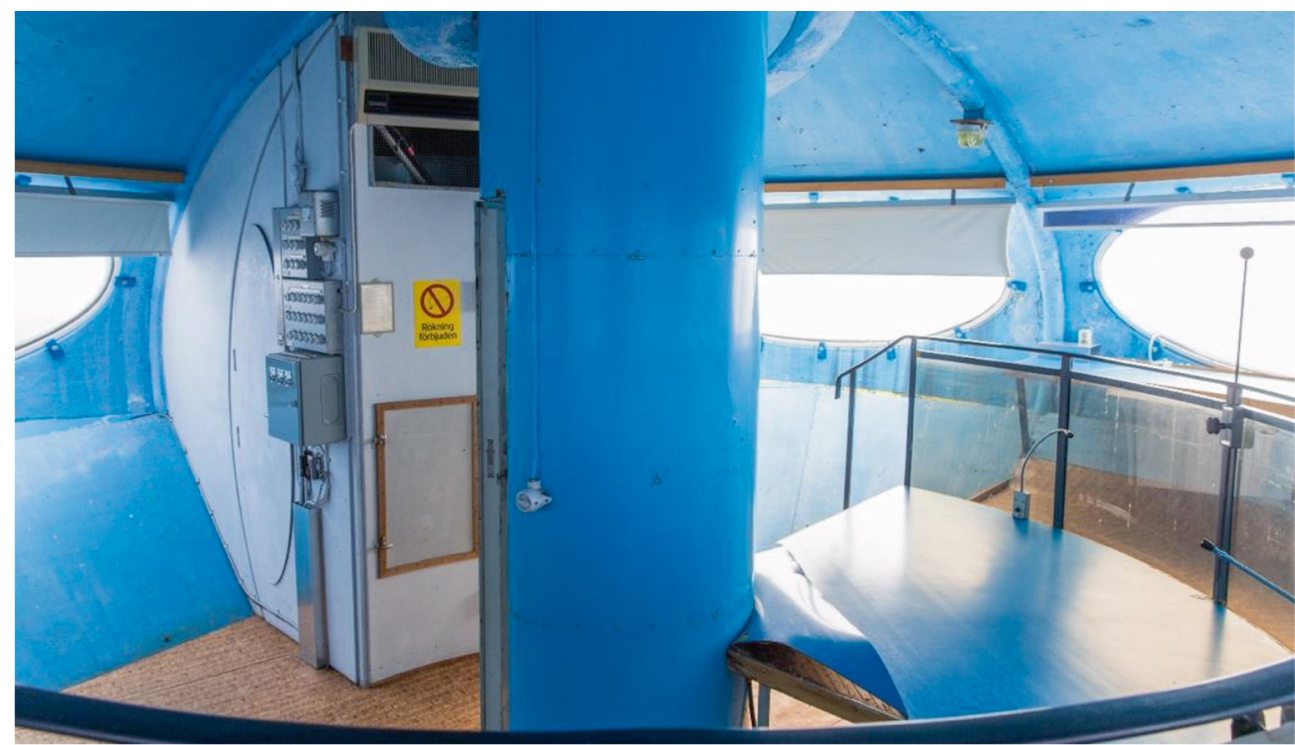

Figure 6: Interior, tower no. 2. (ㅇ Photo from the Swedish Fortifications Agency with Johan Danielson as photographer.) 


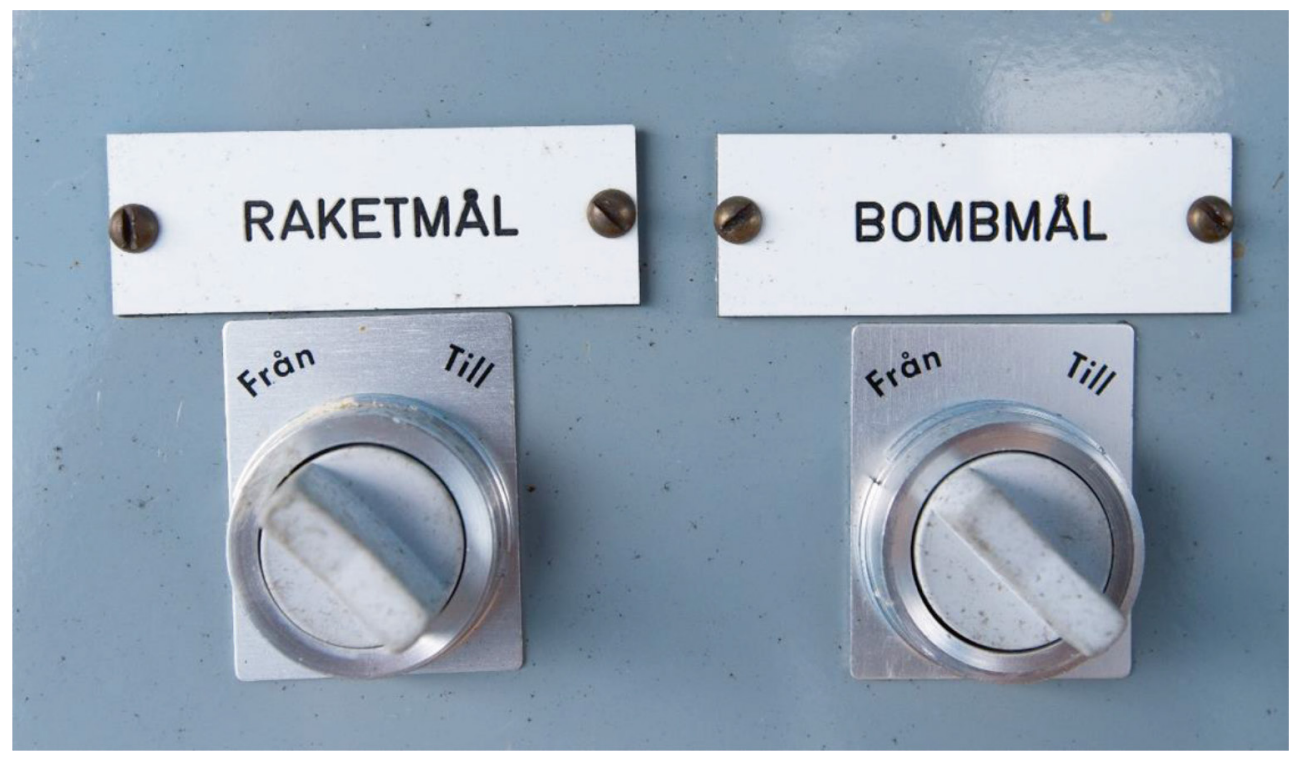

Figure 7: Interior, tower no. 2. Detail of device for handling of the rocket and bomb targets. (C) Photo from the Swedish Fortifications Agency with Johan Danielson as photographer.)

After 1998, the towers were closed in waiting for a decision what to do with them. As the Futuro-houses were situated on top of concrete towers in a remote area, they were not easy to visit for anyone. This made them especially interesting for urban explorers. After one of the towers was broken into, the entrance doors to both towers were welded shut. This did not stop it from happening one more time. Somebody used considerable force to bend the steel door and frame to the side to gain entrance and the roof hatch was thrown to the ground letting birds in. It was therefore important to find a solution on what to do with the towers before more damage was done to them.

\section{PREPARATIONS}

When the Swedish Armed Forces handed over the target area to Fortifications Agency, the work began to prepare the area for civilian use. The first step was to analyse the extension contamination caused by unexploded ordnance (UXO). Luckily, the area with high volumes of UXO was quite small and concentrated to a marshland in the middle of the property.

Next up was the question of what to do with the buildings once used by the Air Force. Some of them had a potential for civilian use without alterations. The Futuro-houses, however, could not serve a civilian purpose in such a remote location.

\section{PRESERVATION VS DISPOSAL}

The first step was to do an evaluation of the heritage values. As little was known about the two towers, a report was written on their history and a discussion began on their value as heritage. The Futuro-houses as such is not unique, there are around 60 still in use all around the world. In Sweden, there are only four Futuro-houses, one in Örebro in the original design and the three military ones that were owned by the Swedish Fortifications Agency, two at Noran and 
one at military airfield in another part of Sweden. The adaptation of them for military use makes them interesting historically but possibly decreases their value as design objects, since they lack several of the original design features.

After having read the report, the Swedish National Heritage Board decided that the towers definitely were worth saving as heritage but realized it was hard to preserve them in their original location if they were to be opened to the public. The number of people that would be able to visit them would be also limited.

The regulation regarding disposal of state property in Sweden secures the opportunity for the state to transfer the property to the rightful state administrator. The receiving part will have no other cost than the book value. As the towers had high cultural value, the National Property Board of Sweden was a natural recipient as the Property Board manages the stateowned cultural heritage that is no longer in use by the military or other state administrations. The Property Board declined taking over responsibility for the Futuro-houses since they saw difficulties in preserving them on site and adapt them for public access. In addition, the costs would be too high as they were two solitary objects in a remote location.

Instead, the Swedish Fortifications Agency passed the question on to another state administration, the Swedish Air Force Museum outside of Linköping and asked if they were willing to take over one of the Futuros as a museum object. They said yes, as they saw the potential of the Futuro-house to tell another kind of history about the Swedish Air Force than for example the airplanes in their collection.

After this input, the Swedish Fortifications Agency took an internal decision to transfer one of the Futuro-houses to the Air Force Museum, while the other one should be sold to the highest bidder on a state web auction. In order to do this, the houses had to be removed from the Noran target area and stored until the final destination was clear.

\section{DISMANTLING AND TRANSPORTATION}

When the decision to move the two Futuro-houses had been made, the Swedish Fortifications Agency looked at different options on how to actually move the buildings. Lifting the Futuro-houses off their towers with a helicopter would be too expensive. Instead, the Swedish Fortifications Agency decided on using a combination of trucking and shipping.

First, the plastic house had to be disconnected from the concrete tower that it was connected to. This could not be done while the house was on top of the tower. Therefore, the top part of the tower was cut with a concrete saw and the upper part was lifted down to the ground. This procedure required exceptional strength from the crane because of the weight of the part of the concrete tower that had to be lifted. After a day of preparations, the first house was lifted to the ground in April 2016, followed by the other one a day later. Local media as well as some of the national press followed the whole process closely as well as an international website specialized in Futuro-houses - thefuturohouse.com (Figs. 8 and 9).

When both houses were on the ground, the plastic construction was disconnected from the concrete. In May, the houses were loaded on two separate trucks. Because of the 8-m diameter, the transport to the Norrsundet port in the Baltic Sea was made in the middle of the night. This way the E4 could be closed down about $12 \mathrm{~km}$ without causing a traffic jam. The transport went well and the houses were then loaded on a boat with a destination port in Norrköping a 2-day journey further south.

When arriving in Norrköping, the procedure was repeated in the reverse order. First, the Futuro-houses were lifted off the boat and then the houses were transported on trucks to Bråvalla, a former air base (Fig. 10). 


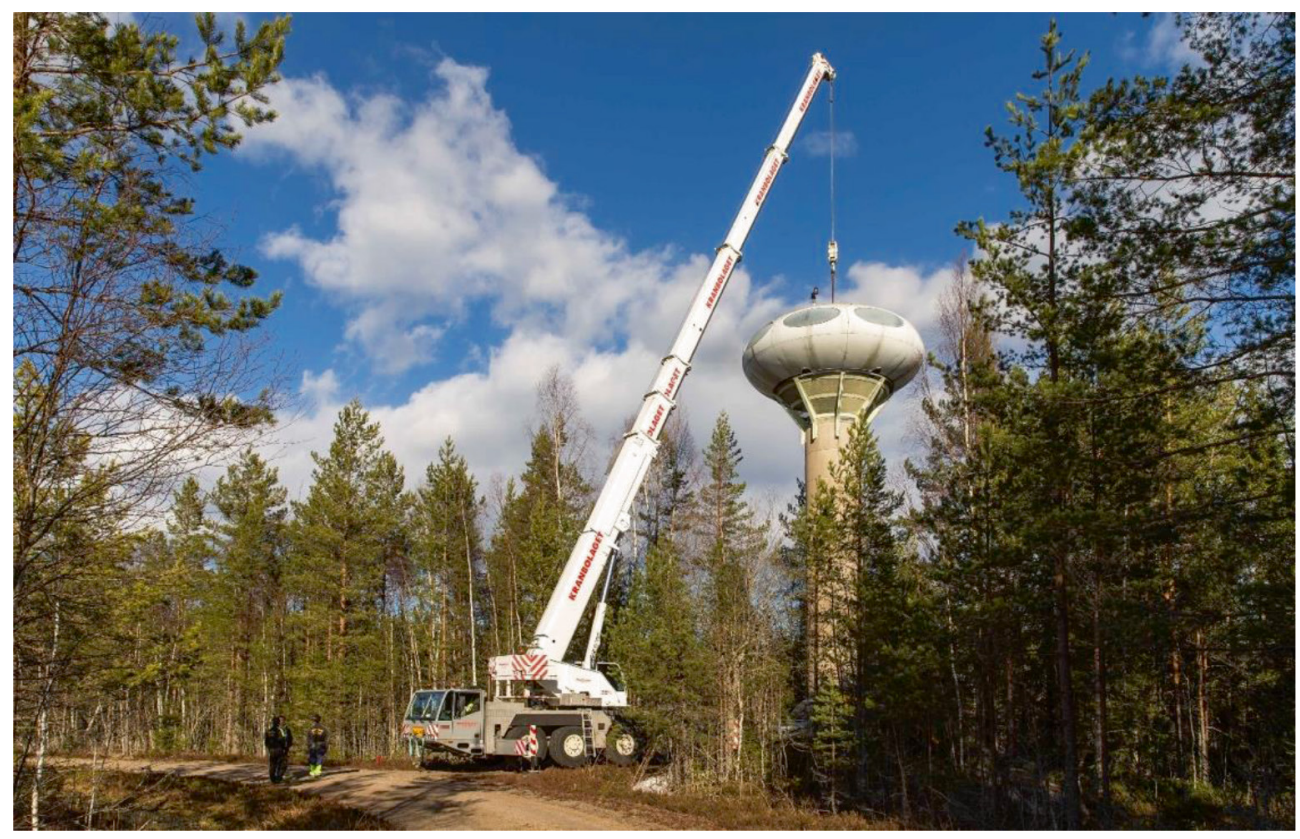

Figure 8: The lifting of Futuro-house on tower no. 1. (ㄷ Photo from the Swedish Fortifications Agency with Johan Danielson as photographer.)

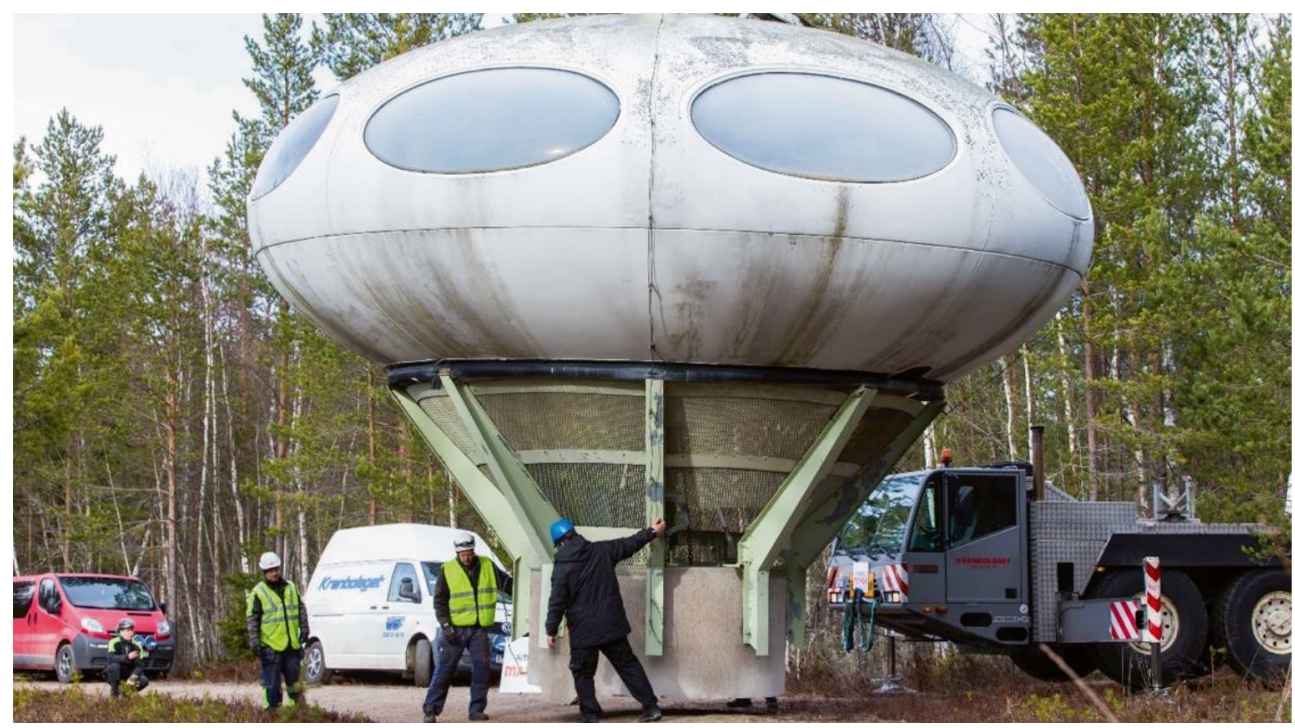

Figure 9: The Futuro-house has landed on the ground. ( Photo from the Swedish Fortifications Agency with Johan Danielson as photographer.) 


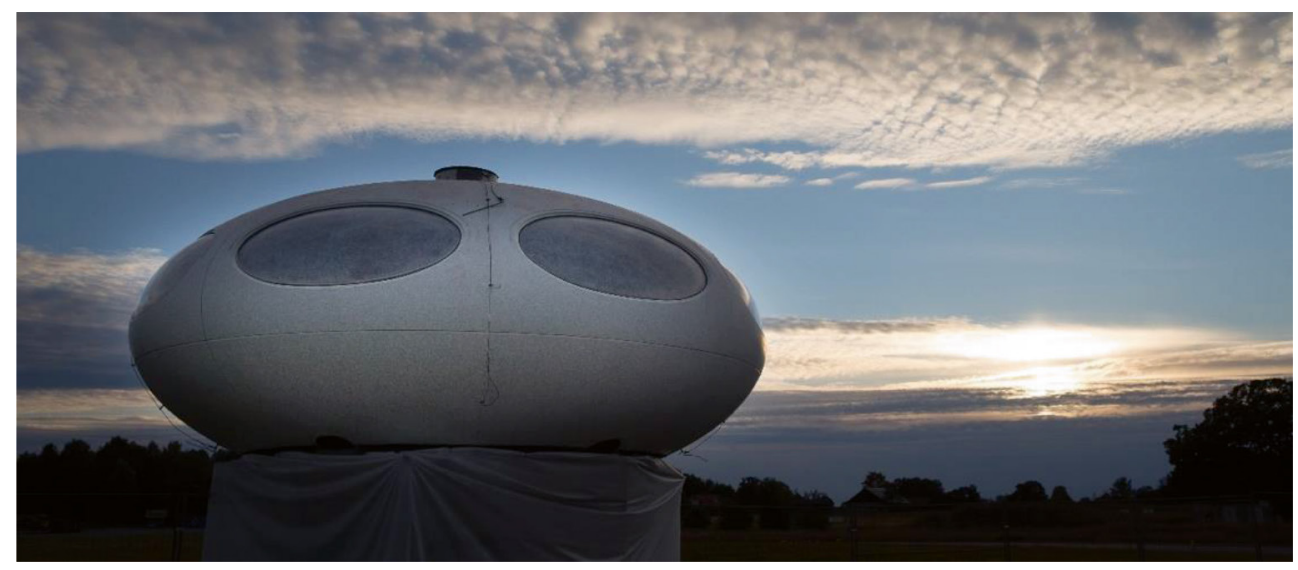

Figure 10: The Futuro-house waiting to be sold in Norrköping. (C Photo from the Swedish Fortifications Agency with Johan Danielson as photographer.)

One of the houses was then transported to the Swedish Air Force Museum in Linköping. Once again one side of the E4 highway had to be closed down at night time. It is now (2017) awaiting its renovation and will be transformed into a conference room.

\section{THE SALES PROCESS}

In order to have an effective sales process, a sales prospect was produced in advance so that the media attention could be taken advantage of. Most of the international interest came from the USA and, of course, Finland were the houses originate. The house sold at an auction in August of 2016 to a Swedish mega fan of the Futuro-houses. She and her partner disassembled the house before moving it. All with the intention of a full renovation before reassembling it at the final destination. The couple already owns an odd building in the southern Swedish town Laholm, Nebotornet. To this, they plan to add the Futuro-house in the garden also possible to book as a hotel room.

\section{REMARKS AND CONCLUSIONS}

The removal of the Futuro-houses was the second best way to preserve the two military Futuro-houses and make it accessible to the public. Preserving them on location and opening them to public in a relatively remote area would have meant that the cost for preserving them would be high and only a limited number of people would have been able to visit them.

Both Futuro-houses will now be opened to the public in different ways, one as a conference room at a museum and one as a privately owned hotel room. Both will probably undergo major interior changes when they are adapted to their new uses. Some or maybe most of the heritage values will inevitably be lost when handling them this way. It can be discussed if this is right or wrong. The Swedish Fortifications Agency, however, still owns a third tower with a Futuro-house identical to the two at Noran. It is therefore possible that this tower can be classified as cultural heritage on site and opened to the public sometime in the future. Until that happens, the remaining Futuro-house tower will be a part of our living military heritage.

\section{REFERENCE}

[1] Wilund arkitekter \& antikvarier/Fortifikationsverket, Futurohusen på Norans före detta skjutfält, Söderhamns kommun, Eskilstuna, Sweden: Wilund arkitekter \& antikvarier/Fortifikationsverket, 2015. 